\title{
Voltammetric study of the adsorbed thermophilic plastocyanin from Phormidium laminosum up to $90{ }^{\circ} \mathrm{C}$
}

\author{
José Luis Olloqui-Sariego a,*, Estrella Frutos-Beltrán ${ }^{\text {b }}$, Emilio Roldán ${ }^{\text {a }}$, Miguel A. De la Rosa ${ }^{\text {b }}$, \\ Juan José Calvente ${ }^{\mathrm{a}}$, Antonio Díaz-Quintana ${ }^{\mathrm{b}}$, Rafael Andreu ${ }^{\mathrm{a}}$ \\ a Departamento de Química Física, Universidad de Sevilla, c/Profesor García González, 1, 41012-Sevilla, Spain \\ ${ }^{\mathrm{b}}$ Instituto de Bioquímica Vegetal y Fotosíntesis, cicCartuja, Universidad de Sevilla y C.S.I.C., Avd. Américo Vespucio 49, 41092 Sevilla, Spain
}

Keywords:

Protein thermostability

Azurin

Plastocyanin

Redox thermodynamics

Protein film voltammetry

Direct electron transfer

\begin{abstract}
A B S T R A C T
Redox thermodynamics and kinetics of plastocyanin from Phormidium laminosum, and of azurin from Pseudonomas aeruginosa, have been investigated as a function of temperature by protein film voltammetry. To this purpose, both proteins have been physisorbed on a pyrolytic graphite edge electrode. A pronounced negative shift of the plastocyanin standard potential, compared to a slight shift in the case of azurin, has been found upon increasing the temperature. Hence, significant conformational and/or solvation changes accompany the redox conversion of plastocyanin. Lower electron transfer rate constants (by c.a. one order of magnitude) and higher activation enthalpies have been found for plastocyanin as compared to azurin. The voltammetric response of azurin vanishes irreversibly at temperatures close to $60{ }^{\circ} \mathrm{C}$, whereas the redox properties of plastocyanin remain unaltered, except for some loss of electroactive protein, after heating the electrode at temperatures as high as $90{ }^{\circ} \mathrm{C}$.
\end{abstract}

\section{Introduction}

A variety of scientific and technological applications have fueled in the last decades a sustained effort to understand the electrochemical behavior of redox proteins [1-3]. The performance of integrated biodevices, such as biosensors or biofuel cells, is known to be often restrained by kinetic limitations. A general approach to overcome these limitations involves an increase of the operating temperature. However, proteins normally become denatured at moderate temperatures, restricting the usefulness of this approach to a small group of thermophilic proteins that keep their structure and functionality at high enough temperatures.

Small cupredoxins, such as plastocyanins and azurins, often display electrochemical reversibility in the adsorbed state, and are good candidates to assess the influence of temperature on their redox properties. Their thermostability has been investigated by spectroscopic techniques in a broad temperature range [4-8], but electrochemical methods, and particularly voltammetry, have been used only up to $50{ }^{\circ} \mathrm{C}$ [9-12].

Herein, we report on the temperature dependence of the redox properties of the thermophilic plastocyanin from Phormidium laminosum at $\mathrm{pH} 7$, close to its physiological $\mathrm{pH}$, and compare the results with those obtained for the non-thermophilic azurin from Pseudonomas aeruginosa at $\mathrm{pH} 4.6$, where its electrochemical response is $\mathrm{pH}$ independent [11].

\footnotetext{
* Corresponding author. Tel.: + 34 954557177; fax: + 34954557174. E-mail address: jlolloqui@us.es (J.L. Olloqui-Sariego).
}

Both proteins were adsorbed onto a pyrolytic graphite edge electrode, and were subjected to cyclic linear potential scan perturbations. Analysis of the resulting voltammograms provided the electron transfer rate constant $\left(\mathrm{k}_{\mathrm{s}}\right)$, the standard potential $\left(\mathrm{E}^{0}\right)$ and the amount of electroactive protein at each temperature. Notably, thermophilic plastocyanin shows an unusual thermal resistance: its redox properties remain unaltered even after being heated at $90{ }^{\circ} \mathrm{C}$.

\section{Materials and methods}

Wild type plastocyanin from $P$. laminosum was expressed in Escherichia coli and purified as described previously [13]. Azurin from $P$. aeruginosa was purchased from Sigma-Aldrich, and was used without further purification. Buffer solutions were prepared from Millipore water and, either anhydrous dihydrogen sodium phosphate from Fluka, or ammonium acetate from Sigma, both being of reagent grade purity.

Pyrolytic graphite (PG) edge electrodes were constructed by fitting a graphite rod from Mineral Technologies, with $0.07 \mathrm{~cm}^{2}$ of exposed geometric area, into a PEEK casing. Prior to each measurement, graphite electrodes were polished using abrasive P1200 sandpaper, and thoroughly rinsed with Millipore water. Either plastocyanin or azurin were physisorbed by depositing a drop of $100 \mu \mathrm{M}$ protein, $5 \mathrm{mM}$ buffer solution on top of the graphite surface for $16 \mathrm{~h}$ at $5{ }^{\circ} \mathrm{C}$.

Linear scan voltammetric measurements were performed with an AUTOLAB PGSTAT 30, from Eco Chemie B.V, in a three electrode undivided glass cell, equipped with a gas inlet and thermostated with a water jacket. The counter and reference electrodes were a Pt bar and 
an $\mathrm{Ag} / \mathrm{AgCl} / \mathrm{NaCl}$ saturated electrode, respectively. The reference electrode was connected to the cell solution via a salt bridge, and kept at room temperature $\left(23 \pm 2{ }^{\circ} \mathrm{C}\right)$ in a non-isothermal configuration. Reported potential values have been corrected to the SHE potential by shifting $+192 \mathrm{mV}$ the experimental potential values. All measurements were carried out under nitrogen atmosphere. Working solutions contained either $5 \mathrm{mM}$ phosphate buffer ( $\mathrm{pH} 7.0$ ), or $20 \mathrm{mM}$ ammonium acetate buffer ( $\mathrm{pH} 4.6$ ), plus $0.1 \mathrm{M} \mathrm{NaCl}$. Their $\mathrm{pH}$ was measured at room temperature with an Orion 8102BN electrode connected to an Orion 420A pH meter. These buffer solutions display a very small variation of $\mathrm{pH}$ with temperature [14], and no attempt was made to account for this effect.

\section{Results and discussion}

Fig. 1 illustrates typical voltammograms of adsorbed plastocyanin (Fig. 1a) and azurin (Fig. 1b). PG edge electrodes have a rough surface [15], which translates into high capacitative currents, and into apparent protein coverages that are bigger than expected for an electroactive protein monolayer on a smooth surface. The full width at half maximum of the azurin peaks coincides with the theoretical value for a one electron exchange of a surface immobilized redox couple. Plastocyanin peaks tend to be broader, as expected for either a distribution of tunneling distances between the protein copper center and the electrode surface, or for a distribution of environments of the adsorbed protein [16]. Standard potential values of the immobilized proteins at $20^{\circ} \mathrm{C}$ (see Table 1 ) are $\sim 20 \mathrm{mV}$ more positive (in the case of plastocyanin), or more negative (in the case of azurin), than their reported values in solution $[17,18]$. These standard potential shifts indicate a further stabilization of the reduced form of plastocyanin and of the oxidized form of azurin, upon adsorption at the graphite surface.

As the scan rate is being increased, the two voltammetric peaks depart progressively from each other, producing trumpet plots, as those depicted in Fig. 1c and d for both proteins. Solid lines in these plots are theoretical fits computed by simulation using a finite difference procedure from the high reorganization energy $(\lambda)$ limit (i.e. for $\left.\lambda>F\left|E_{p}-E^{0}\right|\right)$ of the Marcus electron transfer theory [19], with addition of a small finite peak separation to account for the persistent low scan rate peak splitting. Electron transfer rate constants for plastocyanin and azurin at $20^{\circ} \mathrm{C}$ are listed in Table 1 . As it is often the case with members of this protein family $[12,20]$, electron exchange is about ten times faster for azurin than for plastocyanin.

To assess the influence of temperature on the voltammetric response, the electrode with the adsorbed protein was kept inside the electrochemical cell for $\sim 6 \mathrm{~h}$, while the temperature was first increased from $0{ }^{\circ} \mathrm{C}$ to $90{ }^{\circ} \mathrm{C}$ and then lowered back to $0{ }^{\circ} \mathrm{C}$, with stops to record voltammograms at different scan rates every $10^{\circ} \mathrm{C}$. It should be noted that the electroactive surface concentrations of both plastocyanin (Fig. 1e) and azurin (Fig. 1f) decrease along this thermal cycle, due to either irreversible denaturation or desorption. This protein loss is most severe in the case of azurin, and restricts its voltammetric analysis to the forward thermal scan, and just up to $60{ }^{\circ} \mathrm{C}$. Notably, plastocyanin remains electroactive to allow its quantitative characterization along the whole thermal cycle.

Fig. 2 shows the variation with temperature of the standard potential and electron transfer rate constant of these two proteins. It should be noted that the redox properties of plastocyanin are the same in the forward and backward thermal scans (Fig. 2, open and closed symbols), providing strong evidence in favor of its full redox activity at $90^{\circ} \mathrm{C}$. Besides, the slopes of the $\mathrm{E}^{0}$ vs. T plots (i.e. the $\Delta S_{r c}^{0}$ values associated with protein reduction) in Fig. 2a point to significant differences in the way these two adsorbed proteins rearrange their structure upon changing their oxidation state. As a comparison, the entropy changes reported for three azurins and three non-thermophilic plastocyanins in solution lie within the $-68 \leq \Delta S_{r c}^{0} / \mathrm{J} \mathrm{mol}^{-1} \mathrm{~K}^{-1} \leq-10$ range [21]. We have found a similar value for adsorbed azurin (see Table 1 ), but
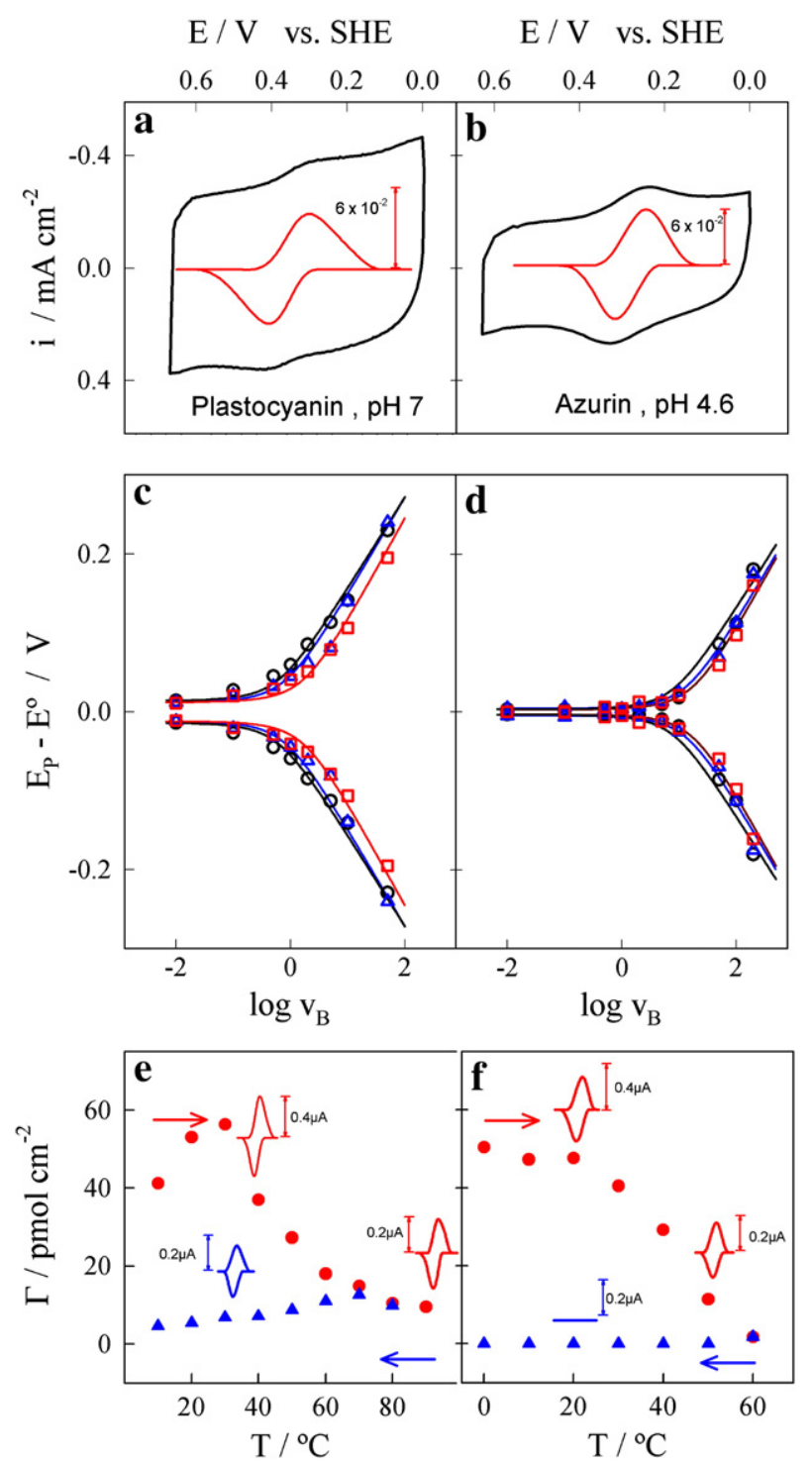

Fig. 1. Voltammetric features for plastocyanin (left panels) and azurin (right panels) adsorbed at a PG edge electrode. (a and b) Raw and background-corrected cyclic voltammograms recorded at $20^{\circ} \mathrm{C}$ and $1 \mathrm{~V} \mathrm{~s}^{-1}$. (c and d) Anodic and cathodic peak potentials as a function of the logarithm of the scan rate at distinct temperatures (black circles) $20{ }^{\circ} \mathrm{C}$; (blue triangles) $40{ }^{\circ} \mathrm{C}$ and (red squares) $60{ }^{\circ} \mathrm{C}$. (e and f) Variation of the protein coverage with temperature during the heating (red circles) and cooling (blue triangles) thermal scans. Typical voltammograms are included as insets.

the $\Delta S_{r c}^{0}$ values for the thermophilic plastocyanin in this work are more negative, and decrease further upon increasing the temperature (from -71 to $-147 \mathrm{~J} \mathrm{~mol}^{-1} \mathrm{~K}^{-1}$ within the tested temperature range). It is interesting to note that the $\Delta S_{r c}^{0}$ values reported in Ref. [11] for azurin at pH $5.0\left(-8 \mathrm{~J} \mathrm{~mol}^{-1} \mathrm{~K}^{-1}\right), 6.4\left(-10 \mathrm{~J} \mathrm{~mol}^{-1} \mathrm{~K}^{-1}\right)$ and $7.7\left(-14 \mathrm{~J} \mathrm{~mol}^{-1} \mathrm{~K}^{-1}\right)$ indicate that the change of solution $\mathrm{pH}$

Table 1

Redox parameters of plastocyanin and azurin adsorbed at a PG edge electrode at $20^{\circ} \mathrm{C}$.

\begin{tabular}{|c|c|c|c|c|c|}
\hline \multirow[t]{2}{*}{ Protein } & \multirow{2}{*}{$\begin{array}{l}\mathrm{E}^{0}(\mathrm{mV}) \\
\text { vs. } \mathrm{SHE}^{\mathrm{a}}\end{array}$} & \multirow{2}{*}{$\frac{\Delta S_{r c}^{0}}{\left(\mathrm{~J} \mathrm{~mol}^{-1} \mathrm{~K}^{-1}\right)}$} & \multirow{2}{*}{$\frac{\Delta H_{r c}^{0}}{\left(\mathrm{~kJ} \mathrm{~mol}^{-1}\right)}$} & \multirow{2}{*}{$\frac{k_{\mathrm{s}}}{\left(\mathrm{s}^{-1}\right)^{\mathrm{b}}}$} & \multirow{2}{*}{ 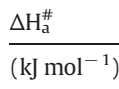 } \\
\hline & & & & & \\
\hline & $355 \pm 10$ & $-80 \pm 13$ & $-60 \pm 9$ & $10 \pm 2$ & $15.5 \pm 1.0$ \\
\hline Azurin & $315 \pm 10$ & $-13 \pm 3$ & $-36 \pm 2$ & $150 \pm 6$ & $12.5 \pm 1.5$ \\
\hline
\end{tabular}

a Estimated from the average of anodic and cathodic peak potentials.

b Estimated from Marcus electron transfer theory in the high reorganization energy limit. 

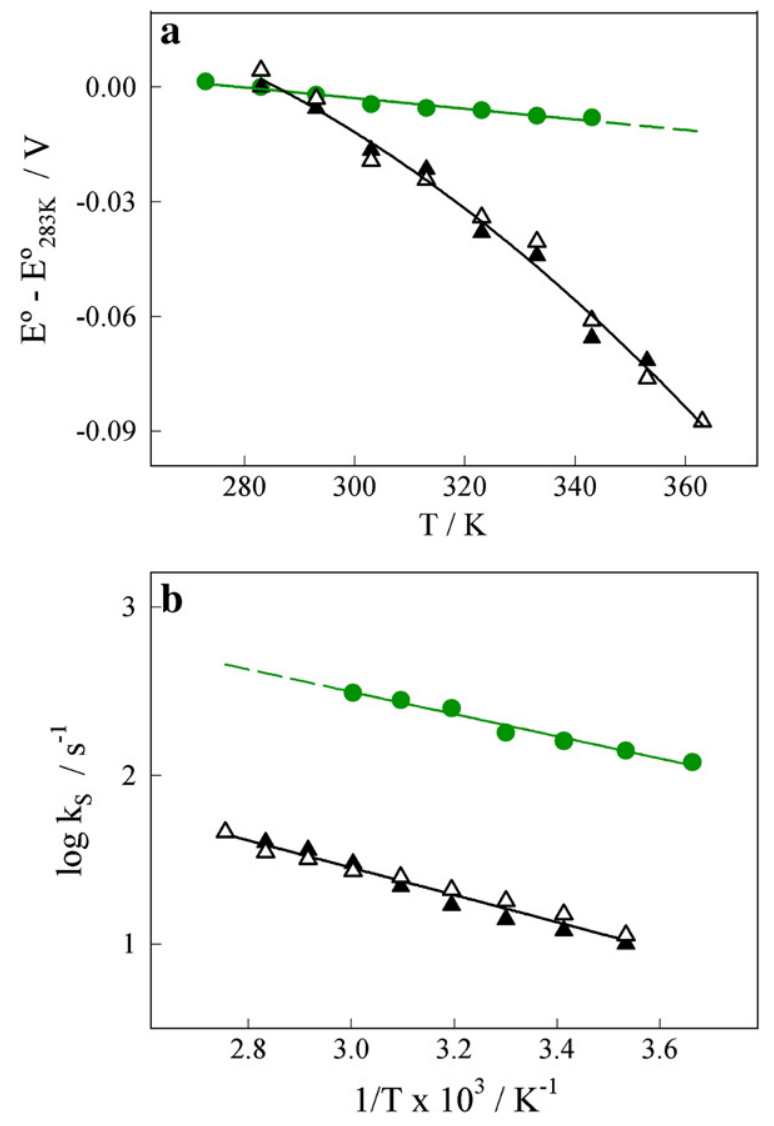

Fig. 2. (a) Temperature dependence of the standard redox potential and (b) Arrhenius plots for plastocyanin (black) and azurin (green) adsorbed at a PG edge electrode. Closed symbols were obtained during the heating thermal scan, and open symbols during the reverse cooling scan.

only accounts for a small part of the big difference we have observed between the $\Delta S_{r c}^{0}$ values for azurin at $\mathrm{pH} 4.6\left(-13 \mathrm{~J} \mathrm{~mol}^{-1} \mathrm{~K}^{-1}\right)$ and plastocyanin at $\mathrm{pH} 7\left(-80 \mathrm{~J} \mathrm{~mol}^{-1} \mathrm{~K}^{-1}\right)$. The same trend is obtained when the enthalpy changes $\Delta H_{r c}^{0}$ for non-thermophilic plastocyanins and azurins in Ref. [21] (that lie between -36 and $-50 \mathrm{~kJ} \mathrm{~mol}^{-1}$ ), are compared with our results in Table 1 , and more specifically with $\Delta H_{r c}^{0}$ values for plastocyanin that vary between -58 and $-72 \mathrm{~kJ} \mathrm{~mol}^{-1}$ upon increasing temperature. Noteworthy, the change in redox state of plastocyanin is accompanied by progressively bigger conformational and/or solvational changes as the temperature is being increased, whereas this effect is absent for the adsorbed azurin.

The slopes of the linear Arrhenius plots in Fig. 2b provide the activation enthalpy $\left(\Delta \mathrm{H}_{\mathrm{a}}^{\#}\right)$ values for interfacial electron transfer listed in Table 1. It is interesting to note that the values of $\mathrm{k}_{\mathrm{s}}$ and $\Delta \mathrm{H}_{\mathrm{a}}^{\#}$ for azurin are very close to those recently reported for the same protein adsorbed at an undecanethiol monolayer deposited on gold [22]. This coincidence suggests that the electron exchange between graphite and physisorbed azurin can be characterized by a weak electronic coupling, even though surface and protein are in close contact. If the nonadiabatic regime applies, then the reorganization energy of azurin for electron transfer can be calculated on the basis of $\Delta H_{a}^{\#} \approx \lambda / 4$ [23], giving a value of $0.52 \mathrm{eV}$ that falls within the range of accepted values [22-24]. The same assumptions lead to a somewhat larger reorganization energy value of $0.64 \mathrm{eV}$ for Plastocyanin.

\section{Concluding remarks}

Plastocyanin from $P$. laminosum retains its redox activity at temperatures as high as $90{ }^{\circ} \mathrm{C}$. The comparison of its electrochemical behavior with that of azurin from $P$. aeruginosa shows a marked difference in the rates of variation of their standard potentials with temperature. The energetic and entropic differences between the two redox forms of adsorbed azurin remain nearly temperature independent up to $60{ }^{\circ} \mathrm{C}$, whereas they display a strong variation in the case of plastocyanin, surpassing reported values in literature for similar proteins in solution. One can then wonder whether this abrupt variation of plastocyanin standard potential reflects the structural and/or solvational changes necessary to safeguard its redox activity at high temperatures.

This striking result, though limited to the case of a simple redox protein, can be considered as a first step towards the development of more efficient biotechnological devices operating at high temperatures. To avoid extensive protein desorption at high temperatures, a covalent immobilization procedure is currently underway.

\section{Acknowledgments}

J. L. O., J. J. C. and R. A. acknowledge financial support from the MICINN under grant CTQ 2008-00371 and from the Junta de Andalucía under grant P07-FQM-02492.

E.F.B., M.A.R. and A.D.Q. recognize funding grant P06-CVI-01713 from Junta de Andalucía and MICINN (BFU2009-07190). The authors thank Dr. Irene Díaz-Moreno for her helpful comments.

\section{References}

[1] F.A. Armstrong, H.A. Heering, J. Hirst, Chemical Society Reviews 26 (1997) 169.

[2] J. Hirst, Biochimica et Biophysica Acta 1757 (2006) 225.

[3] C. Léger, P. Bertrand, Chemical Reviews 108 (2008) 2379.

[4] A. Balme, M. Hervás, L.A. Campos, J. Sancho, M.A. De la Rosa, J.A. Navarro, Photosynthesis Research 70 (2001) 281.

[5] M.A. De la Rosa, D. Milardi, D. Grasso, R. Guzzi, L. Sportelli, The Journal of Physical Chemistry 99 (1995) 14864.

[6] A. Díaz-Quintana, J.A. Navarro, M. Hervás, F.P. Molina-Heredia, B. De la Cerda, M.A. De la Rosa, Photosynthesis Research 75 (2003) 97.

[7] M.J. Feio, A. Díaz-Quintana, J.A. Navarro, M.A. De la Rosa, Biochemistry 45 (2006) 4900.

[8] A. Sandberg, D. Harrison, B.G. Karlsson, Biochemistry 42 (2003) 10301.

[9] G. Battistuzzi, M. Bellei, M. Borsari, G.W. Canters, E. de Wall, L.J.C. Jeuken, M. Sola, Biochemistry 42 (2003) 9214.

[10] L.J.C. Jeuken, J.P. McEvoy, F.A. Armstrong, The Journal of Physical Chemistry. B 106 (2002) 2304.

[11] S. Monari, G. Battistuzzi, C. Dennison, M. Borsari, A. Ranieri, M. Jan Siwek, M. Sola, Journal of Physical Chemistry C 114 (2010) 22322.

[12] A. Ranieri, G. Battistuzzi, M. Borsari, S. Casalini, C. Fontanesi, S. Monari, M. Jan Siwek, M. Sola, Journal of Electroanalytical Chemistry 626 (2009) 123.

[13] M.J. Feio, J.A. Navarro, M.S. Teixeira, D. Harrison, B.G. Karlsson, M.A. De la Rosa, Biochemistry 43 (2004) 14784

[14] R.G. Bates, Determination of pH: Theory and Practice, John Wiley \& Sons, New York, 1973.

[15] C.F. Blanford, F.A. Armstrong, Journal of Solid State Electrochemistry 10 (2006) 826.

[16] L.J.C. Jeuken, Biochimica et Biophysica Acta 1604 (2003) 67.

[17] Q. Chi, J. Zhang, E.P. Friis, J.E.T. Andersen, J. Ulstrup, Electrochemistry Communications 1 (1999) 91.

[18] F.J. Muñoz-López, E. Frutos-Beltrán, S. Díaz-Moreno, I. Díaz-Moreno, G. Subías, M.A. De la Rosa, A. Díaz-Quintana, FEBS Letters 584 (2010) 2346.

[19] K. Weber, S.E. Creager, Analytical Chemistry 66 (1994) 3164

[20] L. Andolfi, D. Bruce, S. Cannistraro, G.W. Canters, J.J. Davis, H.A.O. Hill, J. Crozier, M.P. Verbeet, C.L. Wrathmell, Y. Astier, Journal of Electroanalytical Chemistry 565 (2004) 21.

[21] G. Battistuzzi, M. Borsari, L. Loschi, F. Righi, M. Sola, Journal of the American Chemical Society 121 (1999) 501.

[22] D.E. Khoshtariya, T.D. Dolidze, M. Shushanyan, K.L. Davis, D.H. Waldeck, R. Van Eldik, Proceedings of the National Academy of Sciences 107 (2010) 2757

[23] M. Cascella, A. Magistrato, I. Tavernelli, P. Carloni, U. Rothlisberger, Proceedings of the National Academy of Sciences 103 (52) (2006) 19641.

[24] H.B. Gray, B.G. Malmström, R.J.P. Williams, Journal of Biological Inorganic Chemistry 5 (2000) 551. 